NOT
IN
THIS
FAMILY 


\title{
POLITICS AND CULTURE \\ IN MODERN AMERICA
}

\begin{abstract}
Series Editors
Glenda Gilmore, Michael Kazin, and Thomas J. Sugrue

Volumes in the series narrate and analyze political and social change in the broadest dimensions from 1865 to the present, including ideas about the ways people have sought and wielded power in the public sphere and the language and institutions of politics at all levels-local, national, and transnational. The series is motivated by a desire to reverse the fragmentation of modern U.S. history and to encourage synthetic perspectives on social movements and the state, on gender, race, and labor, and on intellectual history and popular culture.
\end{abstract}



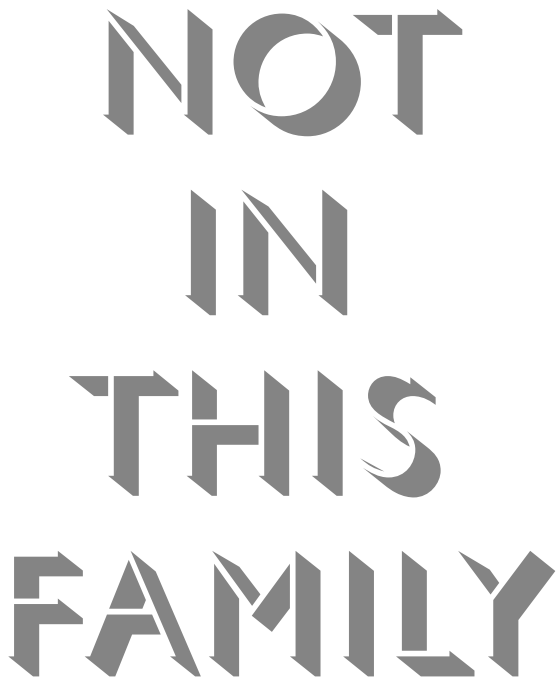

Gays and the Meaning of Kinship in Postwar North America

\title{
Heather Murray
}

\author{
$\overline{\text { PENN }}$ \\ UNIVERSITY OF PENNSYLVANIA PRESS \\ PHILADELPHIA · OXFORD
}


Copyright (C) 2010 University of Pennsylvania Press

All rights reserved. Except for brief quotations used for purposes of review or scholarly citation, none of this book may be reproduced in any form by any means without written permission from the publisher.

\author{
Published by \\ University of Pennsylvania Press \\ Philadelphia, Pennsylvania 19104-4112 \\ Printed in the United States of America \\ on acid-free paper \\ $\begin{array}{llllllllll}10 & 9 & 8 & 7 & 6 & 5 & 4 & 3 & 2 & 1\end{array}$
}

\title{
Library of Congress Cataloging-in-Publication Data
}

Murray, Heather A. A.

Not in this family : gays and the meaning of kinship in postwar North America / Heather A. A. Murray.

p. $\mathrm{cm}$.

Includes bibliographical references and index.

ISBN 978-0-8122-4268-3 (hardcover : alk. paper)

1. Gay men-United States-History-20th century. 2. Gay men-Family relationships-United States-History-20th century. I. Title.

HQ76.M87 2010

306.76'62097309045-dc22 